シンポジウム：䛮噮

\title{
8．輪状咽頭筋支配神経起始核について
}

———逆行性軸索輸送法（HR P 法）による研究——

*吉田 義一，文野＼cjkstart実

\section{Symposium: Dysphagia, Its Clinical and Basic Investigations}

\section{Localization of Motor Neurons Innervating the Cricopharyngeal}

\section{Muscle in the Cat Using the Horseradish Peroxidase Method}

\author{
Yoshikazu Yoshida, M.D. and Minoru Hirano, M.D.
}

Department of Otorhinolaryngology, Kurume University, School of Medicine, Kurume

The motoneurons innervating the cricopharyngeal muscle of cats were identified by utilizing retrograde axonal transport of horseradish peroxidase (HRP).

HRP was injected into the cricopharyngeal muscle in eight cats, the thyreopharyngeal muscle in four cats and the rostral part of esophagus in four cats.

After injection of HRP into the cricopharyngeal muscle, HRP-labeled motoneurons were found in the ipsilateral retrofacial nucleus and the rostral part of the nucleus ambiguus.

The labeled neurons were most frequently observed through the levels between the rostral part and middle part of rostrocaudal extent of the inferior olivary nucleus.

脑幹の損傷にて惹起される麻盘性與下障害に 対して，近年積極的な手術療法がなされるよう になってきた。中でも輪状咽頭筋切断術は1951 年Kaplan ${ }^{1)}$ の報告以来，一般に普及している。 これは臨床所見として上・中および下咽頭収縮 筋が麻舫しているにもかかわらず，輪状咽頭筋 のみが正常か，または却って tonic な状態がみ られ，このため食物の通過がうまくいかないか らである。この理由として Kramer2) は1957年 に上部咽頭筋の支配は第IXおよび第X脳神経を 通じて迷走神経疑核の運動細胞から直接受けて いるのに対し，輪状咽頭筋は機能的に咽頭筋よ りむしろ食道筋の一部々みなされるので迷走神 経背側核から支配を受けるからだと報告してい る。このことが輪状咽頭筋切断の根拠となって きた。ところで一般に迷走神経核は知覚性打よ び副交感性の背側核と特殊内臓遠心性の疑核と

*久留米大学医学部耳鼻咽喉科学教室
内臟求心性の孤束核などがあり，背側核はさら に外側部の知覚核と咽頭, 喉頭, 食道粘膜など を支配している内側部の副交感性起始核に区別 されている。括約筋である輪状咽頭筋が迷走神 経背側核に支配されているという説は，この点 からやや納得できないものがある。そこでわれ わ机は1971年 Kristensson ${ }^{3)}$ の発表以来，神経 解剖学の研究に用いられるようになった horseradish peroxidase 法（以下, HRP と略す）に よってこの点を追求した。

本研究にはネコ（体重 800 2000g, 雌雄 16 匹)を用いた。HRP 注入部位は輪状咽頭筋 ( 8 例）と対照として甲状咽頭筋（4例）ならびに 食道上部（4例）である。ネコを深麻酔下に手 術顕微鏡を使って被験筋を露出し，30〜 $50 \% \mathrm{H}$ $\mathrm{RP}$ 溶解液を注入した。注入後 48 時間で還流固 定し脳幹摘出後, 凍結連続切片を作製, Colman 法に準じたベンチジンによる反応，次いで 


\section{吉田義一・他論文付図}
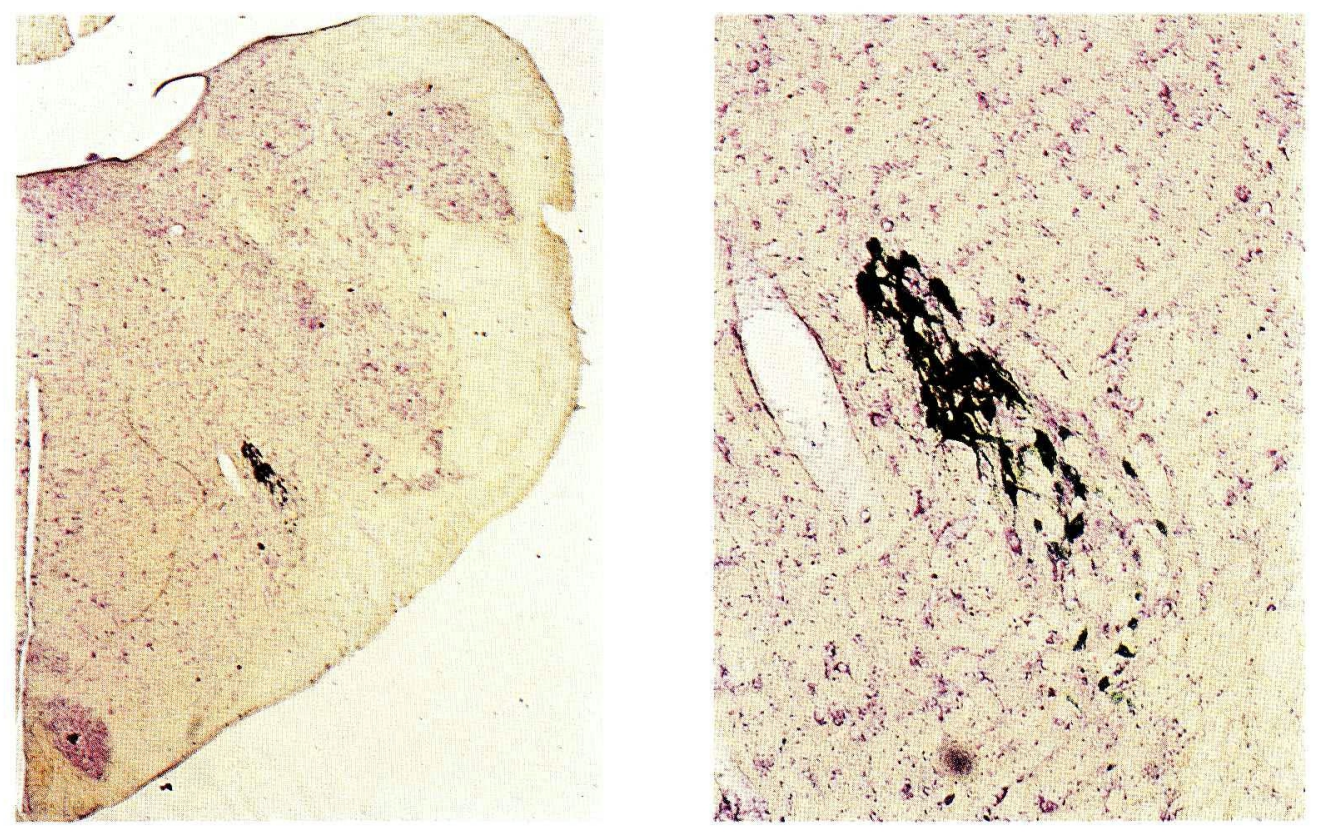

図 1 輪状咽頭筋HRP注入例

左図は弱拡大 $(\times 8)$ 、延髄の下オリーブ核の上部を通る高さの横 断面で、HRPにより標識された起始核がNucleus retrofacialisに 認められる。

右図は強拡大 $(\times 80)$ 、暗緑色に反応した標識細胞の樹状突起なら びにその起始部に顆粒を含んでいるのが認められる。 
スライドグラスに貼り付けて Cresyl violet 対比染色し封入の後に明視野鏡検 在行った。注入した筋は筋電図で確認し 写真撮影を行的た。

HRP 注入により標識された細胞はす べて注入したと同じ側に認められた。輪 状咽頭筋に注入した例の標識細胞標本を 図 1 亿示す。左は弱拡大で見たもので, 標識細胞が Nucleus retrofacialis に認め られるが，迷走神経背側核には認められ ない。これは延髄の下オリーブ核の上部 を通る高さの横断面である。右は強拡大 で標識された細胞が暗緑色に反応し密集 しているのが判る。また樹状突起とその 起始部に顆粒を含んでいるのが観察でき る。各個体について連続切片による横断 面をAから $\mathrm{G}$ な゙゙の 7 つレベルに分け て検討した。すなわちレベル A は顔面神 経根と上オリーブ核が見られ，Bでは顔
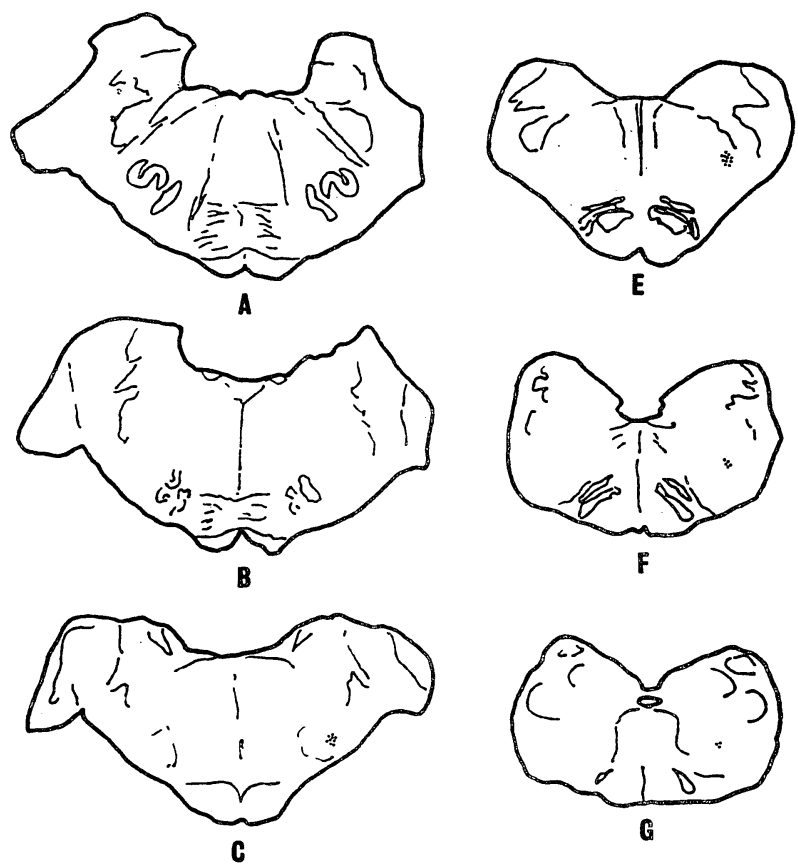
面神経膝があり上オリーブ核の下部の高 さ，Cは顔面神経核の下端部で下オリ一 ブ核がまだ出現していない高さ，Dは下 オリーブ核の上部を通る高さ， E は下オ リーブ核の中程の高さ，F は Obex より やや上で下オリーブ核の下部の高さ， G は Obex よりやや下を通る高さで下オリ

ーブ核の下端部の高さに分けた。このようにし て輪状咽頭筋注入例 8 個体を検討し要約したも のを図 2 亿示す。標識細胞はレベル Cすなわち 顔面神経核の下部の高さよりレベル Gすなわち Obex の高さまでで Nucleus retrofacialis おう び疑核に連なる一連の column を形成し, 最む 標識細胞の多く見られる高さは，レベルうと $\mathrm{E}$ すなわち下オリーブ核の上部から中程の高さの 断面である。なお標識細胞は迷走神経背側核に はす心゙ての断面を通しても見られなく，かつ両 側性に標識細胞の現われた例もない。次に同様 な手法で刘照とした甲状咽頭筋ならびに食道上 部注入例をみたところ，標識細胞はわずかに輪 状咽頭筋の起始核よりずれた位置に認められ た。

以上これまでに検索し得た点をまとめると (1) 輪状咽頭筋の注入例においては, Nucleus retrofacialis より疑核に至る細胞柱を形成し，下オ

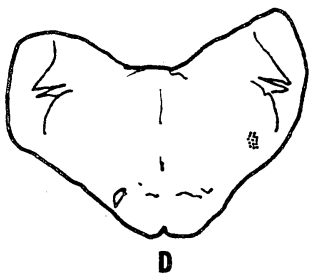

図 2 輪状咽頭筋 HRP 注入例 標識細胞は顔面神経核の下部(レベルC)から Obex に至る Nucleus retrcfacialis および疑核に連なる 一連の column を形成し, 最も標識細胞数が多くみ られる高さは，下オリーブ核の上部（レベルD）か ら中程（レベルE）の高さである。

リーブ核の上部の高さから中程までの高さの間 に標識細胞が最も多く認められた。(2)対照とし て注入した甲状咽頭筋々食道上部计輪状咽頭筋 の起始核よりわずかにずれた位置に認められ た。(3)今回の実験では迷走神経背側核には標識 細胞注認られなかった。(4)輪状咽頭筋は両側 の起始核より支配を受けている事実は認められ なかった。

終りに本研究に際し, 九州大学医学部第三解剖学 教室, 金関毅教授, 十時忠秀助手の御親切な御指導 に农心より感謝の意を表します。 
日気食会報，31（2），1980

\section{参 考 文 献}

1) Kaplan, S. : Paralysis of deglutition, a postpoliomyelitis complication treated by section of the cricopharyngeus muscle. Ann. Surg., 133 : 572-573, 1951.

2 ) Kramer, P. et al.: The dynamics of swallowing. II. Neuromuscular dysphagia of pharynx. J. Clin. Invest., 36 : 589-595, 1957.
3 ) Kristensson, K. et al. : Axonal uptake and retrograde transport of exogenous proteins in the hypoglossal nerve. Brain Research, 32 : 399-406, 1971.

$\left(\begin{array}{rr}\text { 別刷請求： }=810 \text { 福岡市中央区赤坂 } 1-12-8 \\ \text { 吉田 } & \text { 義一 }\end{array}\right)$ 